\title{
Cell-Mediated and Humoral Immune Response to 2-Dose SARS-CoV2 mRNA vaccination in Immunocompromised patient population
}

Muthukumar Ramanathan ${ }^{1}$, Kanagavel Murugesan ${ }^{1}$, Lu M. Yang ${ }^{1}$, Cristina Costales ${ }^{1}$, Philip L. Bulterys ${ }^{1}$, Joseph Schroers-Martin ${ }^{2}$, Ash A. Alizadeh ${ }^{2}$, Scott D. Boyd ${ }^{1,3}$, Janice M. Brown ${ }^{4}$, Kari C. Nadeau ${ }^{3,5}$, Sruti S. Nadimpalli ${ }^{6}$, Aileen X. Wang ${ }^{7}$, Stephan Busque ${ }^{8}$, Benjamin A. Pinsky $^{1,4}$, Niaz Banaei ${ }^{1,4,9}$

${ }^{1}$ Department of Pathology, Stanford University School of Medicine, Stanford, CA 94305 USA

${ }^{2}$ Department of Medicine, Division of Oncology, Stanford University School of Medicine, Stanford, CA 94305 USA

${ }^{3}$ Sean N. Parker Center for Allergy \& Asthma Research, Stanford, CA 94305 USA

${ }^{4}$ Department of Medicine, Division of Infectious Diseases and Geographic Medicine, Stanford University School of Medicine, Stanford, CA 94305 USA

${ }^{5}$ Department of Medicine, Division of Pulmonary, Allergy \& Critical Care Medicine, Stanford University School of Medicine, Stanford, CA 94305 USA

${ }^{6}$ Department of Pediatrics, Division of Pediatric Infectious Diseases, Stanford University School of Medicine, Stanford CA 94305 USA

${ }^{7}$ Department of Medicine, Division of Nephrology, Stanford University School of Medicine, Stanford, CA 94305 USA

${ }^{8}$ Department of Surgery, Division of Abdominal Transplantation, Stanford University School of Medicine, Stanford, CA 94305 USA

${ }^{9}$ Clinical Microbiology Laboratory, Stanford Health Care, Palo Alto, CA 94304 USA 
medRxiv preprint doi: https://doi.org/10.1101/2021.07.21.21260921; this version posted July 23, 2021. The copyright holder for this preprint (which was not certified by peer review) is the author/funder, who has granted medRxiv a license to display the preprint in perpetuity. It is made available under a CC-BY-NC-ND 4.0 International license .

\section{Abstract}

Characterization of cell-mediated and humoral immune responses to SARS-CoV2 mRNA vaccine has implications for protective immunity in immunocompromised patients. However, studies have demonstrated poor humoral response to SARS-CoV2 mRNA vaccine in immunocompromised patients and data on cellular immune response are currently lacking. Here we compared immune response after 2-dose vaccination in 100 immunocompromised patients (solid organ transplant recipients, hematologic malignancy, autoimmune condition, and primary immunodeficiency) and 16 immunocompetent healthy healthcare workers. We find that $100 \%(\mathrm{Cl}=80.6-100 \%)$ of immunocompetent individuals show positive cell-mediated and humoral immune response post vaccination while only $50 \%(\mathrm{Cl}=40.4-59.6 \%)$ of immunocompromised patients show humoral immune response and $69 \%(\mathrm{Cl}=59.4-77.2 \%)$ have a positive cellmediated immune response. $21 \%$ of immunocompromised patients have no humoral immune response or cell-mediated immune response and thus are likely vulnerable to SARS-CoV2 infection. Monitoring of immune response in immunocompromised populations, particularly in high-risk immunocompromised patients (solid organ transplant recipients, patients with severe autoimmunity, and those $\geq 50$ years), with clinical IGRA and serological assay after vaccination may identify patients who may benefit from revaccination or prophylactic monoclonal antibody therapy to prevent COVID-19 in this patient population 
medRxiv preprint doi: https://doi.org/10.1101/2021.07.21.21260921; this version posted July 23, 2021. The copyright holder for this preprint (which was not certified by peer review) is the author/funder, who has granted medRxiv a license to display the preprint in perpetuity.

It is made available under a CC-BY-NC-ND 4.0 International license .

One in 25 Americans are estimated to be immunocompromised ${ }^{1}$. Characterization of cellmediated and humoral immune responses to SARS-CoV2 vaccine has implications for protective immunity in this vulnerable population. However, studies have demonstrated poor humoral response to SARS-CoV2 mRNA vaccine in immunocompromised patients ${ }^{2}$ and data on cellular immune response are currently lacking. Hence, the nature of cellular immune response in immunocompromised patients after standard 2 dose mRNA vaccination is unclear compared to immunocompetent individuals, in whom the vaccine trials demonstrated robust cellular and humoral immune responses.

Here, we compared cell-mediated and humoral immune responses to SARS-CoV-2 mRNA vaccination in immunocompromised patients and immunocompetent controls. Clinically orderable laboratory-developed interferon- $\gamma$ release assay (IGRA) was performed to measure and qualitatively interpret T-cell response to SARS-CoV2 antigens. Humoral response was evaluated using a commercial ELISA assay measuring lgG for the SARS-CoV-2 spike S1 domain.

Immunocompetent controls (16 healthy healthcare workers, median age 42 [IQR 36-47]; $38 \%$ men) provided informed consent for post-vaccination immune response testing after (median 17 days [IQR 15-18]) the second dose of BNT162b2 mRNA vaccine. Immunocompromised patients (100 patients, median age 56 [IQR 36-68]; 54\% men) were tested by their providers after (median 50 days [IQR 45-79]) the second dose of Moderna or Pfizer/BioNTech mRNA vaccine . Immunocompromised patients comprised four subgroups solid organ transplant $(n=21)$, hematologic malignancy $(n=38)$, autoimmune condition treated with antimetabolite drugs or biologics $(n=17)$ or primary immunodeficiency $(n=24)$.

$100 \%(95 \%$ confidence interval $(\mathrm{Cl})=80.6-100 \%)$ of immunocompetent controls had a positive IGRA qualitative result compared to $69 \%(\mathrm{Cl}=59.4-77.2 \%)$ in all immunocompromised patients (Figure 1A). However, there was no significant difference in median interferon- $Y$ 
medRxiv preprint doi: https://doi.org/10.1101/2021.07.21.21260921; this version posted July 23, 2021. The copyright holder for this preprint (which was not certified by peer review) is the author/funder, who has granted medRxiv a license to display the preprint in perpetuity.

It is made available under a CC-BY-NC-ND 4.0 International license .

response in controls when compared with immunocompromised patients $(1.29 \mathrm{IU} / \mathrm{mL}$ vs 1.23 $\mathrm{IU} / \mathrm{mL} ; \mathrm{p}=0.2)$ (Figure 1B). All $16(100 \%, \mathrm{Cl}=80.6-100 \%)$ controls had a positive qualitative antibody result compared to $50 \%(\mathrm{Cl}=40.4-59.6 \%)$ positivity rate in immunocompromised patients (Figure 1C). Immunocompetent controls had higher median antibody IgG levels compared to immunocompromised patients (12 vs 2.42 OD ratio, $p<0.0001$ ) (Figure 1D). In $29 \%$ of immunocompromised patients, cell-mediated response was the only positive immune response to the vaccine compared with $10 \%$ for whom IgG was the only positive immune response (Supplementary Figure 1).

Comparing cell-mediated and humoral immune responses among all immunocompromised patients, no significant difference was noted based on mRNA vaccine manufacturer (Moderna vs Pfizer/BioNTech) or sex (Supplementary Figure 2). However, immunocompromised patients below the age of 50 had 5 -fold higher median lgG levels than patients age 50 or older (5.90 vs 1.21 OD ratio; $p<0.001)$. No significant difference was noted in cell-mediated response based on age among immunocompromised patients (Supplementary Figure 3).

This study demonstrates that immunocompromised patients have a higher rate of positive cell-mediated response (69\%, $\mathrm{Cl}=59.4-77.2 \%)$ than humoral response $(50 \%$, $\mathrm{Cl}=40.4 \%-59.6 \%)$ to SARS-CoV-2 mRNA vaccine and interferon- $\gamma$ levels are comparable between immunocompetent controls and immunocompromised patients. IgG levels, however, were significantly lower in the latter group. The absence of either cell-mediated or humoral immune response was highest in solid organ transplant recipients $(38.1 \%)$ and patients with autoimmune disorders (35.3\%) (Supplementary Figure 4).

Prior studies in patients with influenza have demonstrated that cell-mediated immune response to influenza virus in the absence of humoral response correlates with protection against symptomatic influenza ${ }^{4}$. Further studies are required to confirm protection against 
medRxiv preprint doi: https://doi.org/10.1101/2021.07.21.21260921; this version posted July 23, 2021. The copyright holder for this preprint (which was not certified by peer review) is the author/funder, who has granted medRxiv a license to display the preprint in perpetuity. It is made available under a CC-BY-NC-ND 4.0 International license.

COVID-19 in vaccinated, immunocompromised patients with cell-mediated immune response alone. In contrast to immunocompetent healthcare workers, in whom $100 \%$ had positive cellular and humoral immune response, this study revealed that a significant fraction (21\%) of immunocompromised patients mount no cellular or humoral response after vaccination and likely remain susceptible to infection with ancestral strains or emerging variants of SARS-CoV2. Monitoring of immune response in immunocompromised populations, particularly in high-risk immunocompromised patients (solid organ transplant recipients, patients with severe autoimmunity, and those $\geq 50$ years), with clinical IGRA and serological assay after vaccination may identify patients who may benefit from revaccination ${ }^{5}$ or prophylactic monoclonal antibody therapy to prevent COVID-19 in this patient population. 
medRxiv preprint doi: https://doi.org/10.1101/2021.07.21.21260921; this version posted July 23, 2021. The copyright holder for this preprint (which was not certified by peer review) is the author/funder, who has granted medRxiv a license to display the preprint in perpetuity. It is made available under a CC-BY-NC-ND 4.0 International license.

\section{References}

1. Harpaz R, Dahl RM, Dooling KL. Prevalence of immunosuppression among us adults, 2013. JAMA. 2016;316(23):2547-2548. doi:10.1001/jama.2016.16477

2. Boyarsky BJ, Werbel WA, Avery RK, et al. Antibody response to 2-dose sars-cov-2 mrna vaccine series in solid organ transplant recipients. JAMA. 2021;325(21):2204-2206.

doi:10.1001/jama.2021.7489

3. Kemp SA, Collier DA, Datir RP, et al. SARS-CoV-2 evolution during treatment of chronic infection. Nature. 2021;592(7853):277-282. doi:10.1038/s41586-021-03291-y

4. Sridhar S, Begom S, Bermingham A, et al. Cellular immune correlates of protection against symptomatic pandemic influenza. Nat Med. 2013;19(10):1305-1312. doi:10.1038/nm.3350

5. Kamar N, Abravanel F, Marion O, Couat C, Izopet J, Del Bello A. Three doses of an mrna covid-19 vaccine in solid-organ transplant recipients. N Engl J Med. Published online June 23, 2021. doi:10.1056/NEJMc2108861 
A

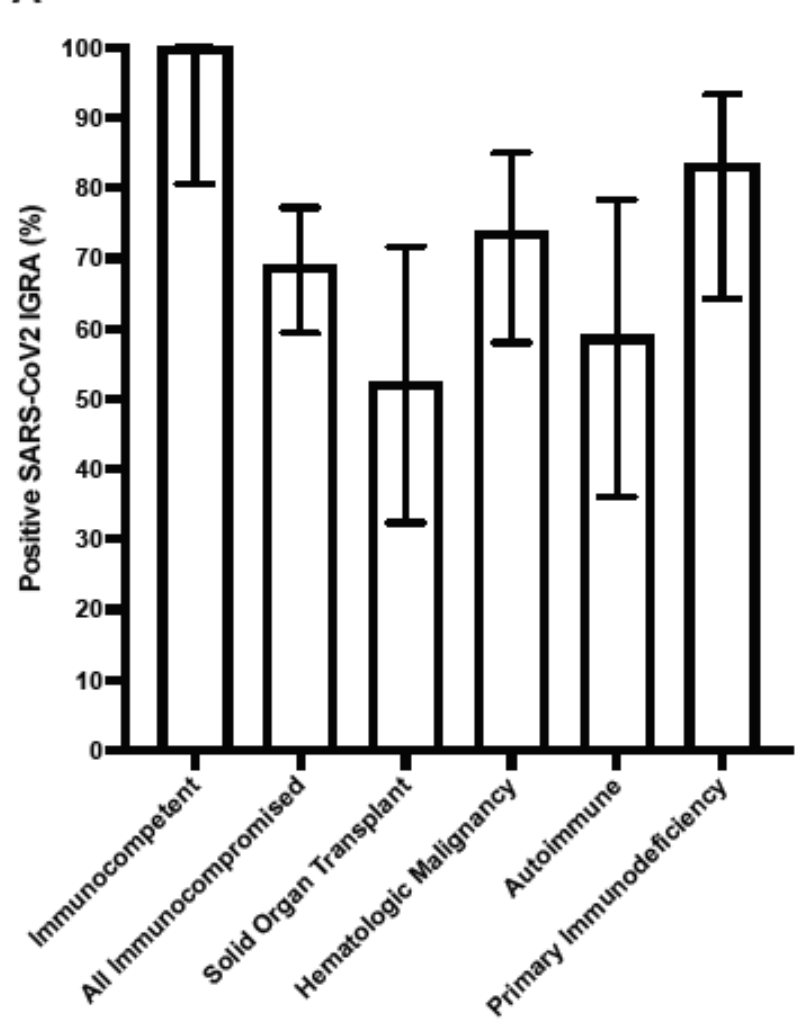

B

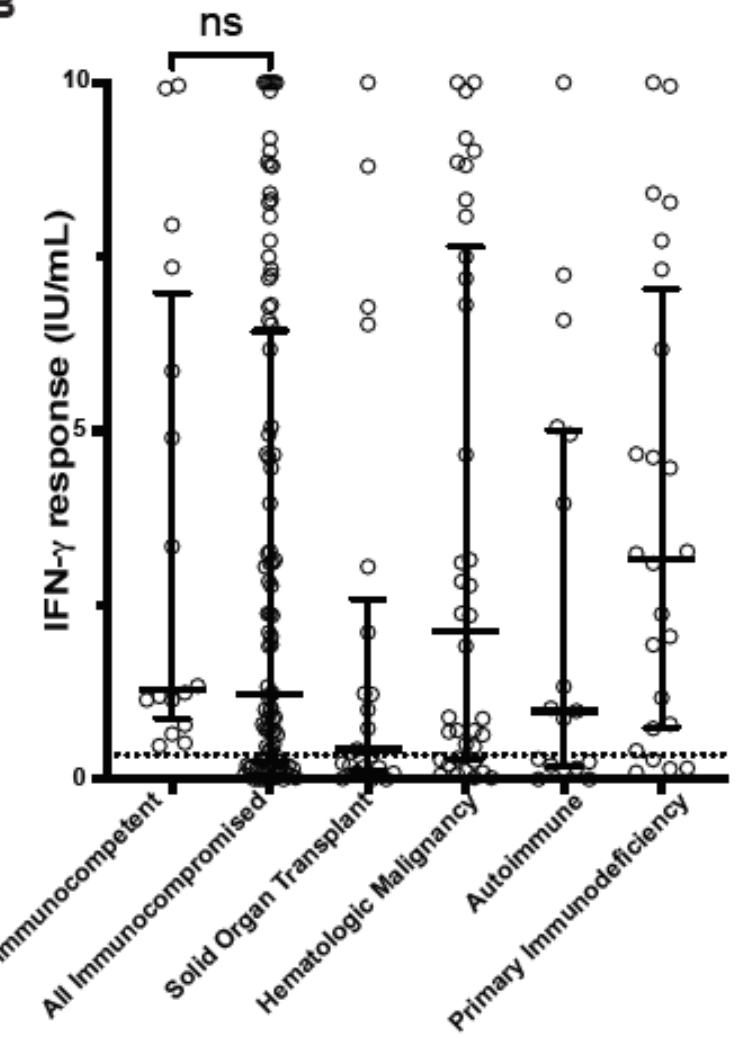

C
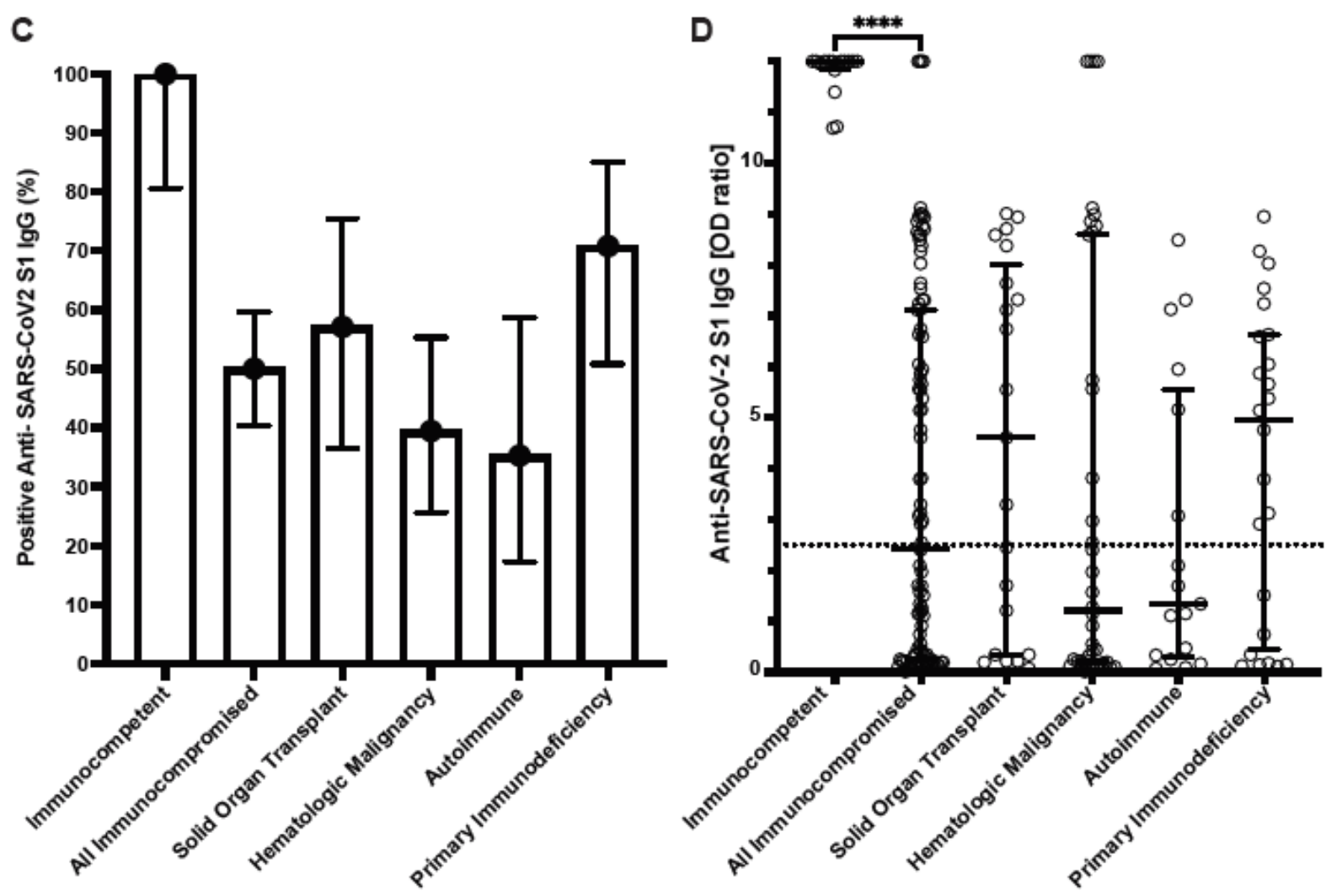
medRxiv preprint doi: https://doi.org/10.1101/2021.07.21.21260921; this version posted July 23, 2021. The copyright holder for this preprint (which was not certified by peer review) is the author/funder, who has granted medRxiv a license to display the preprint in perpetuity.

It is made available under a CC-BY-NC-ND 4.0 International license .

Fig. 1 Cellular and humoral immune responses to SARS-CoV-2 mRNA vaccine in immunocompetent individuals and immunocompromised patients determined with clinical assays.

(A) Percentage of patients with positive SARS-CoV2 interferon-y release assay (IGRA) result. (B) Interferon- $\gamma$ response from IGRA in immunocompetent individuals $(n=16)$ and immunocompromised patients $(n=100)(C)$ Percentage of patients with positive Anti-SARS-CoV2 S1 IgG ELISA result. (D) Anti-SARS-CoV2 S1 IgG optical density (OD) ratio from ELISA performed in immunocompetent and immunocompromised patients. Results for immunocompromised subgroups are also shown. Dotted lines represent the assay cutoffs $(0.35$ IU/mL for IGRA and 2.5 optical density ratio for IgG). Long solid lines show median, short solid lines show $95 \%$ confidence interval. ns, not significant and ${ }^{* * * *}, p<0.0001$ by Mann-Whitney $U$ test. 


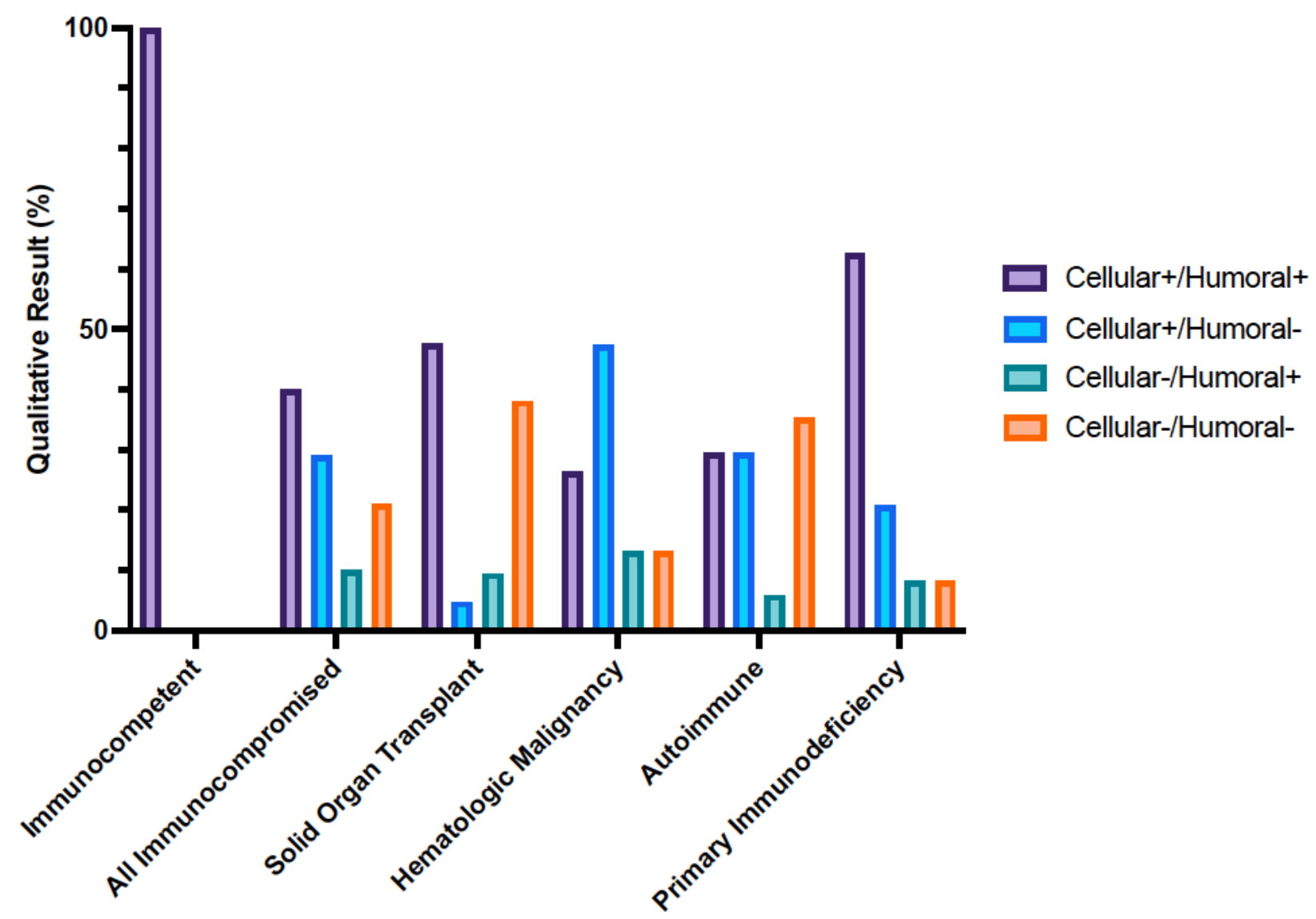

Fig. S1 Cellular and humoral immune responses to SARS-CoV-2 mRNA vaccine in immunocompetent and immunocompromised patients determined with clinical assays.

Percentage of immunocompetent and immunocompromised patients with positive or negative SARS-CoV2 interferon-y release assay and Anti-SARS-CoV-2 S1 IgG ELISA result after 2 doses of SARS-CoV2 mRNA vaccination. 
A

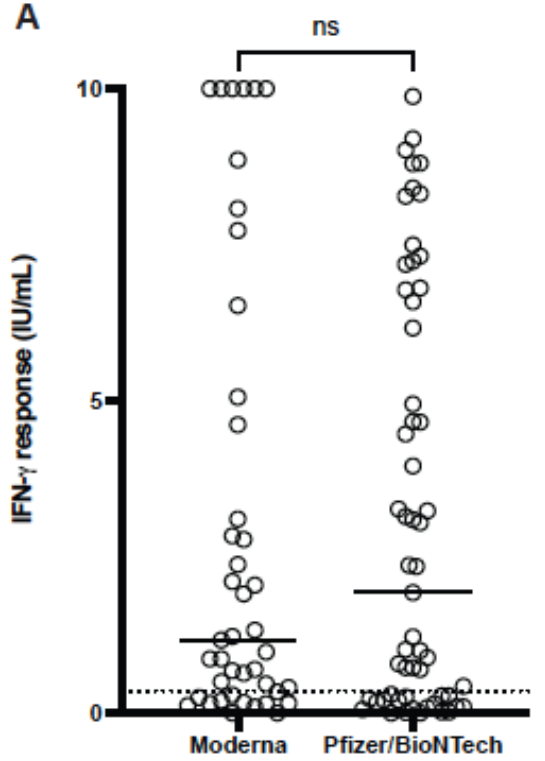

C

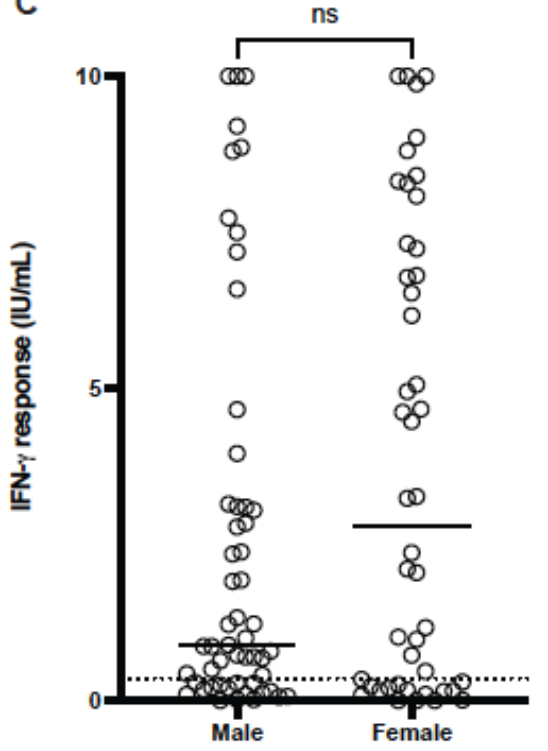

B

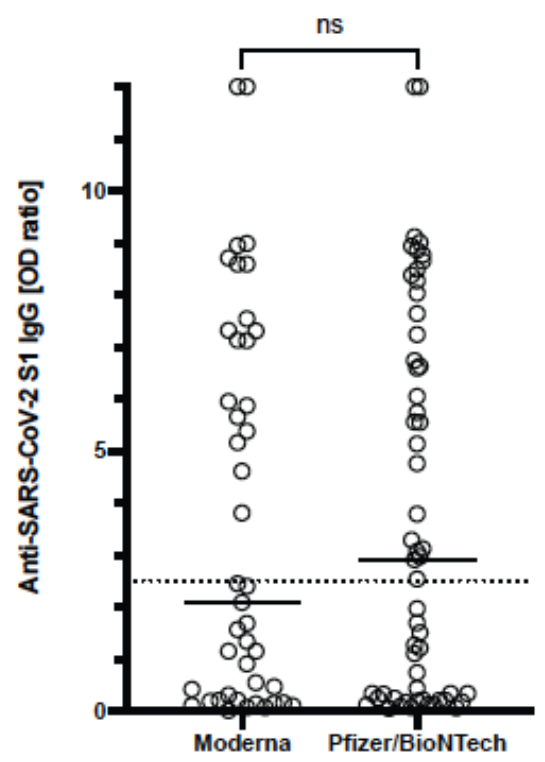

D

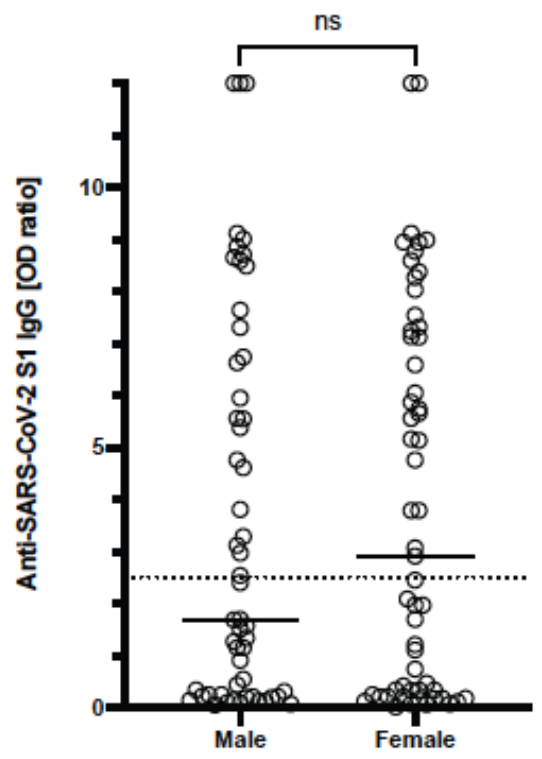

Fig. 52 Cellular and humoral immune responses to SARS-CoV-2 mRNA vaccine in immunocompromised patients based on mRNA vaccine manufacturer and sex.

(A and C) Interferon- $y$ response with interferon- $\gamma$ release assay. (B and D) IgG levels with Anti-SARS-CoV-2 S1 IgG ELISA. Tests were performed in immunocompromised patients $(n=100)$ who received 2 doses of Moderna $(n=43)$ or Pfizer/BioNTech $(n=57)$ SARS-COV2 mRNA vaccine. Dotted lines represent the assay 
cutoffs (0.35 IU/mL for IGRA and 2.5 optical density ratio for IgG). Solid lines show median. ns, not significant by Mann-Whitney U test.

A

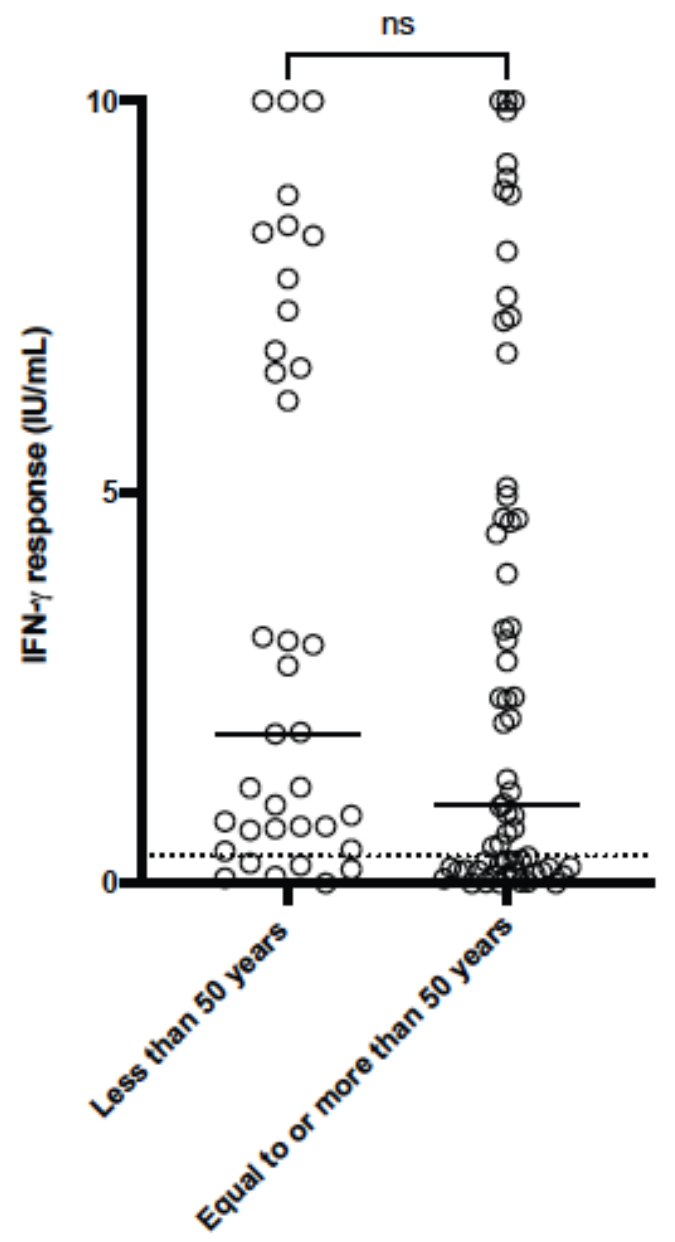

B

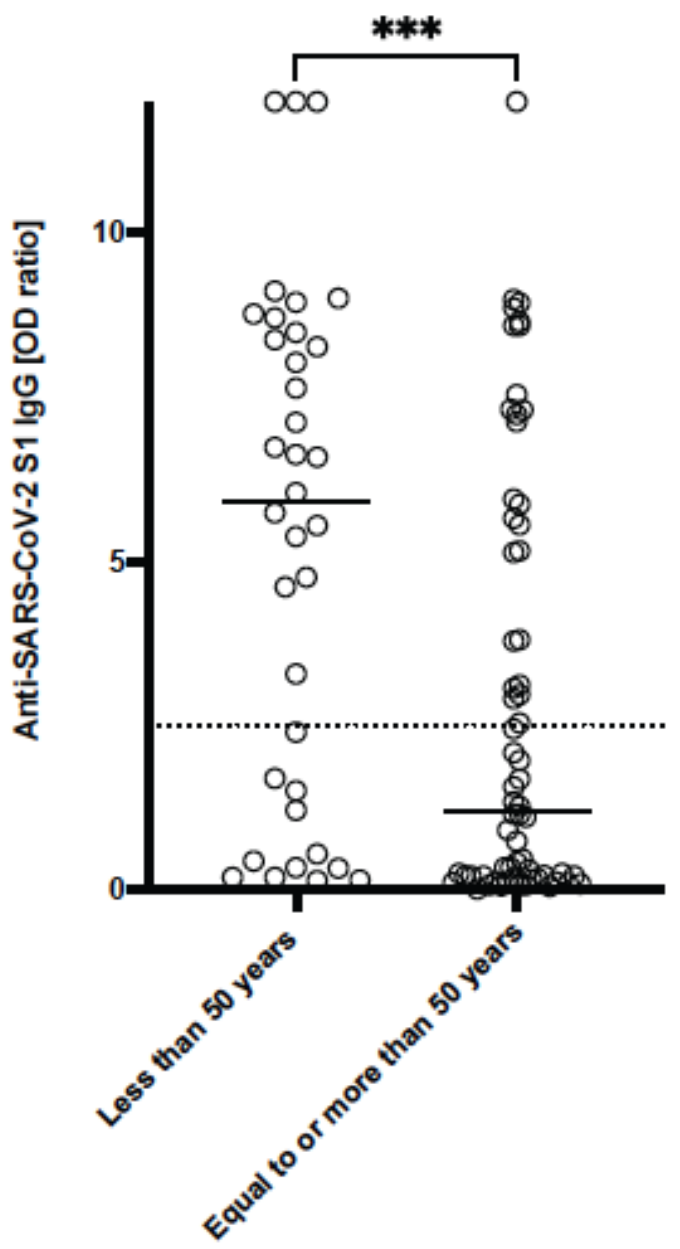

Fig. S3 Cellular and humoral immune responses to SARS-CoV-2 mRNA vaccine in immunocompromised patients based on age. 
medRxiv preprint doi: https://doi.org/10.1101/2021.07.21.21260921; this version posted July 23, 2021. The copyright holder for this preprint (which was not certified by peer review) is the author/funder, who has granted medRxiv a license to display the preprint in perpetuity.

It is made available under a CC-BY-NC-ND 4.0 International license .

(A) Interferon- $y$ response with interferon- $y$ release assay. (B) IgG levels with Anti-SARS-CoV-2 S1 IgG ELISA. Tests were performed in immunocompromised patients $(n=100)$ comparing median age below $50(n=36)$ with 50 or above $(n=64)$. Dotted lines represent the assay cutoffs $(0.35 \mathrm{IU} / \mathrm{mL}$ for IGRA and 2.5 optical density ratio for $\lg G)$. Solid lines show median. $n s$, not significant and ${ }^{* *}, p<0.001$ by MannWhitney U test.

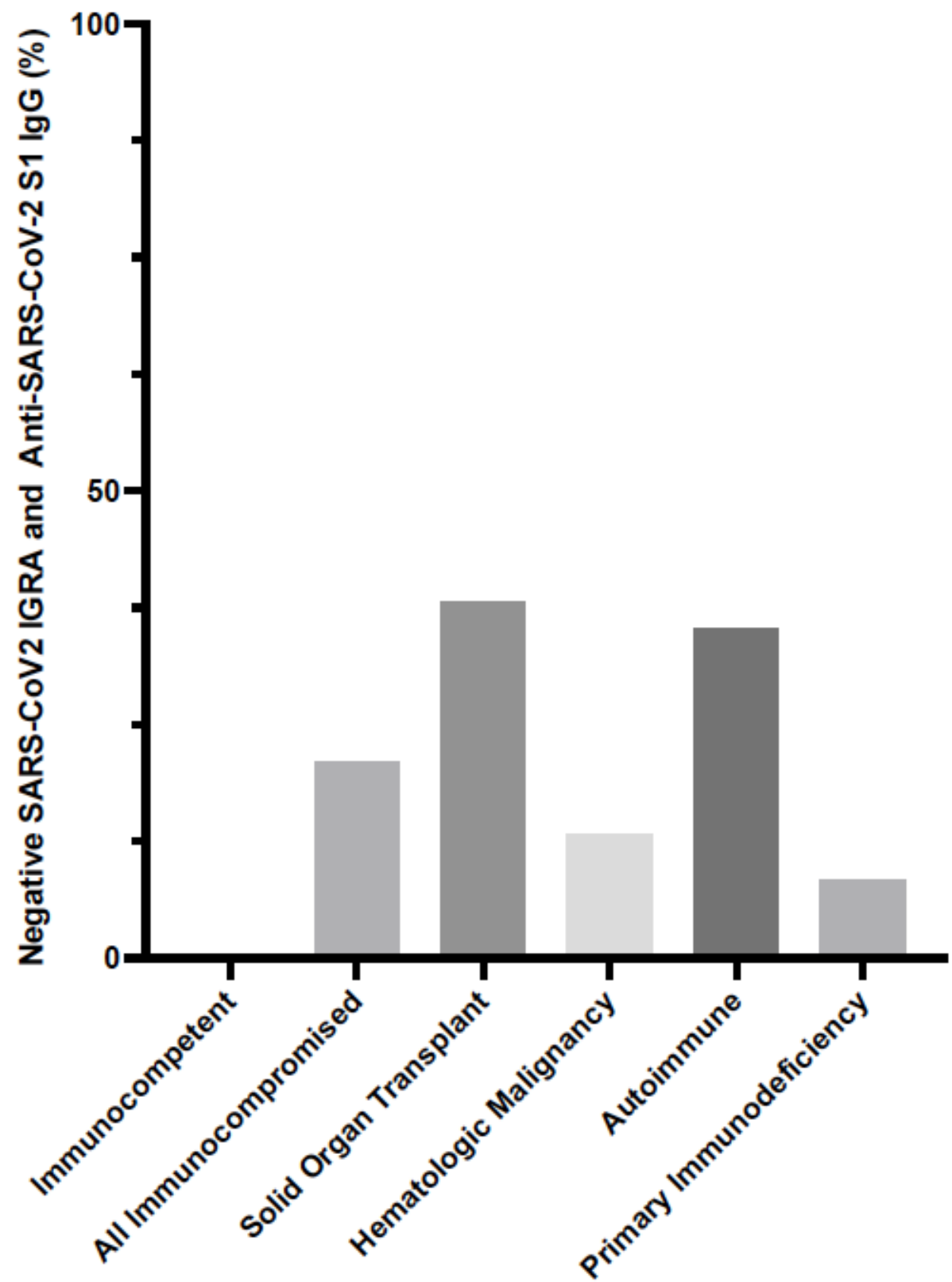


medRxiv preprint doi: https://doi.org/10.1101/2021.07.21.21260921; this version posted July 23, 2021. The copyright holder for this preprint (which was not certified by peer review) is the author/funder, who has granted medRxiv a license to display the preprint in perpetuity.

It is made available under a CC-BY-NC-ND 4.0 International license .

Fig. S4 Negative cellular and humoral immune responses to SARS-CoV-2 mRNA vaccine in immunocompetent and immunocompromised patients determined with clinical assays.

Percentage of patients with negative SARS-CoV2 Interferon-y release assay and negative Anti-SARS-

CoV2 S1 IgG ELISA results after 2 doses of SARS-CoV2 mRNA vaccination. 
medRxiv preprint doi: https://doi.org/10.1101/2021.07.21.21260921; this version posted July 23, 2021. The copyright holder for this preprint (which was not certified by peer review) is the author/funder, who has granted medRxiv a license to display the preprint in perpetuity. It is made available under a CC-BY-NC-ND 4.0 International license .

\section{Material and Methods}

\section{Ethics}

This study was approved by the Stanford University Institutional Review Board (IRB-60171 and IRB-57519). Healthcare worker participants provided informed consent to donate blood samples via venipuncture after second dose of vaccination with BNT162b2. IGRA and IgG ELISA were ordered in immunocompromised patients by their providers as part of clinical testing.

Retrospective chart review of immunocompromised patients was performed to obtained clinical data.

\section{Interferon Gamma Release Assay (IGRA)}

SARS-CoV-2 IGRA was performed in the Stanford Health Care Clinical Microbiology Laboratory as described previously ${ }^{1}$. Freshly collected blood in lithium heparin tube was transferred to BD vacutainer no additive tubes at $1 \mathrm{~mL}$ per tube. One tube was left unstimulated (nil), one tube was stimulated with SARS-CoV-2 antigen peptide megapool (Miltenyi Biotec, Bergisch Gladbach, Germany) at $2.2 \mathrm{mmol} / \mathrm{mL}$, and one tube was stimulated with Phytohemagglutinin PHA-P Mitogen (Sigma, St. Louis, MO) at 50 $\mathrm{L} / \mathrm{mL}$. The blood samples were mixed gently and incubated at $37^{\circ} \mathrm{C}$ for 20 to $24 \mathrm{~h}$. The interferon- $\mathrm{\gamma}$ concentration was measured in the plasma portion with an automated enzyme-linked immunosorbent assay (ELISA) instrument (DSX; Dynex Technologies, Chantilly, VA) using the QuantiFERON-TB ELISA kit (Qiagen, Germantown, MD). Interferon- $y$ response was defined as positive if antigen-nil $\geq 0.35 \mathrm{IU} / \mathrm{mL}$; negative if antigen-nil $<0.35$ and mitogen-nil $\geq 0.5 \mathrm{IU} / \mathrm{mL}$, and indeterminate if nil $>8 \mathrm{IU} / \mathrm{mL}$ or antigen-nil $<0.35$ and mitogen-nil $<0.5 \mathrm{IU} / \mathrm{mL}$. All values higher than $10 \mathrm{IU} / \mathrm{mL}$ were adjusted to $10 \mathrm{IU} / \mathrm{mL}$ to reflect the linear range of assay.

\section{Enzyme-linked immunosorbent assay (ELISA)}


medRxiv preprint doi: https://doi.org/10.1101/2021.07.21.21260921; this version posted July 23, 2021. The copyright holder for this preprint (which was not certified by peer review) is the author/funder, who has granted medRxiv a license to display the preprint in perpetuity. It is made available under a CC-BY-NC-ND 4.0 International license .

SARS-CoV-2 Spike S1 lgG serology was performed by semi-quantitative ELISA (EUROIMMUN, Lübeck, Germany) according to the manufacturer's instructions. Briefly, 1:100 diluted serum samples from vaccinees were added to the antigen pre-coated microplate followed by the addition of anti-human IgG conjugate, chromogenic substrate and stopping solution. The optical density (OD) was measured at $450 \mathrm{~nm}$. Results were evaluated by calculating the ratio of the optical density (OD) of the sample over the OD of a calibrator provided by the manufacturer. Assay cutoff values were defined as follows: $<2.5$ negative, $\geq 2.5$ positive ${ }^{2}$. All values higher than OD 12 were adjusted to 12 to reflect the linear range of assay.

\section{Statistics}

GraphPad Prism version 9.0 (GraphPad Software, San Diego, California, USA) software was used to visualize data and Mann-Whitney $U$ test was performed to compare cellular and humoral response in immunocompetent and immunocompromised patients.

\section{Acknowledgements}

We thank all study participants, providers and nursing staff caring for immunocompromised patients evaluated in this study.

\section{References:}

1. Murugesan $\mathrm{K}$, Jagannathan $\mathrm{P}, \mathrm{Pham} \mathrm{TD}$, et al. Interferon-gamma release assay for accurate detection of SARS-CoV-2 T cell response. Clinical Infectious Diseases 2020; ciaa1537 2. Meyer B, Torriani G, Yerly S, et al. Validation of a commercially available SARS-CoV-2 serological immunoassay. Clinical Microbiology and Infection 2020;26(10):1386-94. 
medRxiv preprint doi: https://doi.org/10.1101/2021.07.21.21260921; this version posted July 23, 2021. The copyright holder for this preprint (which was not certified by peer review) is the author/funder, who has granted medRxiv a license to display the preprint in perpetuity.

It is made available under a CC-BY-NC-ND 4.0 International license. 
Table S1: Demographic and clinical characteristics of study participants (Immunocompetent and Immunocompromised)

\begin{tabular}{|l|l|}
\hline \multicolumn{2}{|c|}{ Immunocompetent (n=16) } \\
\hline Male & $6(37.5 \%)$ \\
\hline Female & $10(62.5 \%)$ \\
\hline Age (Median, IQR) & $42(36-47)$ \\
\hline \multicolumn{2}{|c|}{ Vaccine } \\
\hline A) Pfizer/BioNTech Immune Response \\
\hline B) Moderna & $16(100 \%)$ \\
\hline \multicolumn{2}{|c|}{ Imal } \\
\hline 1) Cellular Positive \& Humoral Positive & $16(100 \%)$ \\
\hline 2) Cellular Positive \& Humoral Negative & $0(0 \%)$ \\
\hline 3) Cellular Negative \& Humoral Positive & $0(0 \%)$ \\
\hline 4) Cellular Negative \& Humoral Negative & $0(0 \%)$ \\
\hline
\end{tabular}

\begin{tabular}{|l|l|}
\hline \multicolumn{2}{|c|}{ Immunocompromised (n=100) } \\
\hline Male & $54(54 \%)$ \\
\hline Female & $46(46 \%)$ \\
\hline Age (Median, IQR) & $56(36-68)$ \\
\hline \multicolumn{2}{|c|}{ Vaccine } \\
\hline A) Pfizer/BioNTech Immune Response \\
\hline B) Moderna & $57(57 \%)$ \\
\hline \multicolumn{2}{|c|}{$43(43 \%)$} \\
\hline 1) Cellular Positive \& Humoral Positive & $40(40 \%)$ \\
\hline 2) Cellular Positive \& Humoral Negative & $29(29 \%)$ \\
\hline 3) Cellular Negative \& Humoral Positive & $10(10 \%)$ \\
\hline 4) Cellular Negative \& Humoral Negative & $21(21 \%)$ \\
\hline
\end{tabular}

\begin{tabular}{|c|c|}
\hline \multicolumn{2}{|c|}{ Solid Organ Transplant (n=21) } \\
\hline Male & $10(47.6 \%)$ \\
\hline Female & $11(52.3 \%)$ \\
\hline Age (Median, IQR) & $39(18-62)$ \\
\hline \multicolumn{2}{|l|}{ Vaccine } \\
\hline A) Pfizer/BioNTech & $13(61.9 \%)$ \\
\hline B) Moderna & $8(38.1 \%)$ \\
\hline \multicolumn{2}{|c|}{ Transplants } \\
\hline Renal Transplant & $15(71.4 \%)$ \\
\hline Liver Transplant & $5(23.8 \%)$ \\
\hline Heart Transplant & $1(4.8 \%)$ \\
\hline \multicolumn{2}{|c|}{ Immune Response } \\
\hline 1) Cellular Positive \& Humoral Positive & $10(47.6 \%)$ \\
\hline 2) Cellular Positive \& Humoral Negative & $1(4.8 \%)$ \\
\hline
\end{tabular}




\begin{tabular}{|l|l|}
\hline \multicolumn{2}{|c|}{ Hematological Malignancy (n=38) } \\
\hline Male & $28(73.6 \%)$ \\
\hline Female & $10(26.3 \%)$ \\
\hline Age (Median, IQR) & $60(40-70)$ \\
\hline \multicolumn{2}{|c|}{ Vaccine } \\
\hline A) Pfizer/BioNTech & $21(55.3 \%)$ \\
\hline B) Moderna Immune Response \\
\hline \multicolumn{2}{|c|}{$17(44.7 \%)$} \\
\hline 1) Cellular Positive \& Humoral Positive & $10(26.3 \%)$ \\
\hline 2) Cellular Positive \& Humoral Negative & $18(47.4 \%)$ \\
\hline 3) Cellular Negative \& Humoral Positive & $5(13.2 \%)$ \\
\hline 4) Cellular Negative \& Humoral Negative & $5(13.2 \%)$ \\
\hline
\end{tabular}

\begin{tabular}{|l|l|}
\hline \multicolumn{2}{|c|}{ Autoimmune condition (n=17) } \\
\hline Male & $8(47.1 \%)$ \\
\hline Female & $9(52.9 \%)$ \\
\hline Age (Median, IQR) & $67(57-71)$ \\
\hline \multicolumn{2}{|c|}{ Vaccine } \\
\hline A) Pfizer/BioNTech & $7(41.2 \%)$ \\
\hline B) Moderna & $10(58.8 \%)$ \\
\hline \multicolumn{2}{|c|}{ Autoimmune condition } \\
\hline Rheumatoid Arthritis Immune Response & $9(52.9 \%)$ \\
\hline Other Autoimmune (MS, CIDP etc) & $8(47.1 \%)$ \\
\hline \multicolumn{2}{|c|}{ Immure } \\
\hline 1) Cellular Positive \& Humoral Positive & $5(29.4 \%)$ \\
\hline 2) Cellular Positive \& Humoral Negative & $5(29.4 \%)$ \\
\hline 3) Cellular Negative \& Humoral Positive & $1(5.9 \%)$ \\
\hline 4) Cellular Negative \& Humoral Negative & $6(35.3 \%)$ \\
\hline
\end{tabular}

\begin{tabular}{|l|l|}
\hline \multicolumn{2}{|c|}{ Primary Immunodeficiency (n=24) } \\
\hline Male & $8(33.3 \%)$ \\
\hline Female & $16(66.7 \%)$ \\
\hline Age (Median, IQR) & $48(34-65)$ \\
\hline \multicolumn{2}{|c|}{ Vaccine } \\
\hline A) Pfizer/BioNTech & $16(66.7 \%)$ \\
\hline B) Moderna & $8(33.3 \%)$ \\
\hline \multicolumn{2}{|c|}{ Immunodeficiency } \\
\hline
\end{tabular}


medRxiv preprint doi: https://doi.org/10.1101/2021.07.21.21260921; this version posted July 23, 2021. The copyright holder for this preprint (which was not certified by peer review) is the author/funder, who has granted medRxiv a license to display the preprint in perpetuity. It is made available under a CC-BY-NC-ND 4.0 International license .

\begin{tabular}{|l|l|}
\hline CVID & $13(54.2 \%)$ \\
\hline Others (Hypogammaglobulinemia etc) & $11(45.8 \%)$ \\
\hline \multicolumn{2}{|c|}{ Immune Response } \\
\hline 1) Cellular Positive \& Humoral Positive & $15(62.5 \%)$ \\
\hline 2) Cellular Positive \& Humoral Negative & $5(20.8 \%)$ \\
\hline 3) Cellular Negative \& Humoral Positive & $2(8.3 \%)$ \\
\hline 4) Cellular Negative \& Humoral Negative & $2(8.3 \%)$ \\
\hline
\end{tabular}

